DOI: $10.19195 / 0137-1134.114 .17$

\author{
MAREK WIERZBOWSKI \\ Uniwersytet Warszawski \\ m.wierzbowski@wpia.uw.edu.pl
}

\author{
MAREK GRZYWACZ \\ Uniwersytet Warszawski \\ m.grzywacz@wpia.uw.edu.pl
}

\title{
O ZMIENIAJĄCEJ SIĘ ROLI POLSKICH UCZELNI W OBSZARZE STUDIÓW PODYPLOMOWYCH, KURSÓW DOKSZTAŁCAJĄCYCH I SZKOLEN'*
}

\begin{abstract}
Abstrakt: Zróżnicowanie przez ustawodawcę statusu słuchacza studiów podyplomowych (oraz uczestników kursów dokształcających i szkoleń) w stosunku do wynikającego z Prawa o szkolnictwie wyższym statusu studenta i doktoranta spowodowało przekształcenie się w tym pierwszym przypadku pierwotnej więzi administracyjnoprawnej (na linii użytkownik zakładu-zakład administracyjny) w relację cywilnoprawną, opartą na umowie, a nie akcie administracyjnym. Wskutek tego wyłączono możliwość stosowania do słuchaczy studiów podyplomowych przepisów kodeksu postępowania administracyjnego oraz niemożliwa stała się kontrola sądowoadministracyjna ze względu na czysto kontraktową więź, objętą właściwością sądów powszechnych.
\end{abstract}

Słowa kluczowe: studia podyplomowe, kursy dokształcające, szkolenia, zakład administracyjny, uczelnia, autonomia

\section{WPROWADZENIE}

Zmieniające się stale warunki otoczenia społeczno-gospodarczego w Rzeczypospolitej Polskiej, mające ogromny wpływ na ostatnie lata funkcjonowania polskich szkół wyższych na podstawie przepisów ustawy z dnia 27 lipca 2005 roku - Prawo o szkolnictwie wyższym ${ }^{1}$, spowodowały konieczność stopniowej ewolucji oferty kierunkowej uczelni ${ }^{2}$ oraz potrzebę poszukiwania nowych obszarów

* Opracowanie zostało przygotowane, gdy nieznany był jeszcze ostateczny kształt projektu ustawy 2.0. Jednakże w świetle proponowanych wstępnych rozwiązań uwagi tu przedstawione pozostają aktualne.

1 Tekst jedn. Dz.U. z 2017 r. poz. 2183 ze zm. (dalej: Prawo o szkolnictwie wyższym lub PSW).

2 Zgodnie z art. 2 ust 1 pkt 1 PSW uczelnią jest szkoła prowadząca studia wyższe, utworzona w sposób określony w ustawie. 
działania edukacyjnego, a co za tym idzie nowych źródeł finansowania ich bieżącej działalności. Jako powody zachodzących zmian można przykładowo wskazać obserwowany od kilkunastu lat znaczący spadek liczby studentów ${ }^{3}$, powiązany z kwestiami demograficznymi w naszym kraju, a także potrzebę kształcenia w nowych obszarach, które kilkanaście lat temu stanowiły tylko wycinek innych dziedzin naukowych lub wyłącznie grupę tematów poruszanych w ramach innego kierunku studiów, czy w końcu powiązaną z poprzednim powodem potrzebę specjalizacji i szybkiego doszkalania się przedstawicieli społeczeństwa w nowych, otaczających ich oraz dynamicznie zmieniających się warunkach gospodarczych. Trendy te obserwujemy również w najbliższym nam obszarze nauk prawnych. Warto jednak zwrócić szczególną uwagę na potrzebę specjalizacji i aktualizacji wiedzy w naszej dziedzinie, która ze względu na liczne krajowe zmiany legislacyjne oraz konieczność wdrażania nowych regulacji przyjmowanych na szczeblu Unii Europejskiej wydaje się szczególnie wrażliwa.

Przez wiele lat najlepszą odpowiedzią na te pojawiające się z różną częstotliwością potencjalne problemy i wyzwania było tworzenie oraz prowadzenie przez uczelnie, a właściwie ich jednostki organizacyjne, studiów podyplomowych o zróżnicowanej tematyce. Zgodnie z art. 2 ust. 1 pkt 11 Prawa o szkolnictwie wyższym przez studia podyplomowe rozumie się formę kształcenia prowadzoną w uczelni, instytucie naukowym Polskiej Akademii Nauk, instytucie badawczym lub Centrum Medycznym Kształcenia Podyplomowego, na którą przyjmuje się kandydatów mających co najmniej kwalifikacje pierwszego stopnia, kończącą się uzyskaniem kwalifikacji podyplomowych. Artykuł 8a Prawa o szkolnictwie wyższym dopowiada, że studia podyplomowe trwają nie krócej niż dwa semestry. Ta ostatnia regulacja dotycząca czasu trwania tej formy szkolenia może być właśnie przyczyną tego, że w bieżących realiach gospodarczych forma studiów podyplomowych stopniowo traci na popularności, a pracodawcy i inni uczestnicy rynku poszukują krótszych lub bardziej intensywnych modeli dokształcania dla siebie lub swoich pracowników. Nierzadko konkretne zapytania w tym przedmiocie kierowane są właśnie do szkół wyższych, których prestiż, pozycja i wysoko wyspecjalizowana kadra naukowo-dydaktyczna gwarantują odpowiedni poziom merytoryczny usługi edukacyjnej. Prawo o szkolnictwie wyższym wprost dopuszcza prowadzenie przez uczelnie oprócz studiów podyplomowych również kursów dokształcających czy właśnie szkoleń (art. 6 ust. 1 pkt 5 PSW), za których pełną realizację, analogicznie do studiów podyplomowych, wydawane są stosowne świadectwa ich ukończenia (art. 6 ust. 1 pkt 6 PSW). Formy te, w związku z przemianami społeczno-gospo-

3 Zgodnie z danymi prezentowanymi przez Główny Urząd Statystyczny w 2005 r., a więc de facto w roku uchwalania Prawa o szkolnictwie wyższym, liczba studentów szkół wyższych w Polsce na 10 tys. mieszkańców wynosiła 508 osób, a w ostatnim w pełni zbadanym roku 2016 współczynnik ten wynosi już tylko 351 osób. Mamy więc już obecnie do czynienia z realnym spadkiem wynoszącym około $30 \%$, a trend ten przez najbliższe kilka lat będzie się zgodnie z prognozami nadal się utrzymywać, http://stat.gov.pl/infografiki-widzety/infografiki/infografika-studenci-17-listopada-miedzynarodowy-dzien-studenta,19,3.html (dostęp: 30.12.2017). 
darczymi, w najbliższym czasie będą zyskiwały zapewne na znaczeniu, a to może powodować wiele problemów organizacyjnych i wewnętrznych w ramach uczelni, a także problemy prawne, które finalnie mogą być rozstrzygane przez sądy, i jak się wydaje, mogą to wcale nie być sądy administracyjne orzekające o legalności wydawanych rozstrzygnięć o charakterze administracyjnym przez polskie uczelnie.

\section{STATUS UCZELNI}

Status uczelni wyższej nie budzi obecnie chyba wątpliwości w doktrynie prawa administracyjnego i orzecznictwie sądów administracyjnych. Każda uczelnia uznawana jest za zakład administracyjny lub stosując inną terminologię — zakład użyteczności publicznej czy zakład publiczny. Zgodnie z uchwałą Naczelnego Sądu Administracyjnego 4 uczelnia to ,jednostka organizacyjna, niebędąca organem państwowym ani organem samorządu, która została powołana do wykonywania zadań publicznych i jest uprawniona do nawiązywania stosunków administracyjnoprawnych. Zakład administracyjny (publiczny), jako jedna z form decentralizacji, nie podlega władzy hierarchicznej organów administracji rządowej i sprawuje funkcje administracji publicznej samodzielnie, korzystając z władztwa zakładowego. [...] Istotę władztwa zakładowego stanowi więc zakres upoważnień dla organów zakładu do jednostronnego kształtowania stosunków prawnych z użytkownikami zakładu (w tym wypadku ze studentami), jak również osobami które znalazły się na terenie zakładu w innym charakterze (np. jako osoby pragnące skorzystać z księgozbioru biblioteki uniwersyteckiej). [...] grupa społeczna złożona z użytkowników zakładu ma zawsze (w danym przedziale czasu) charakter mniej lub bardziej zamknięty".

Nie ma tu miejsca na szczegółową analizę pojęcia „władztwo zakładowe”, jednakże należy pamiętać, że możliwość korzystania z władztwa zakładowego wynika w większości przypadków ze stosunku o charakterze administracyjnoprawnym, łączącego użytkownika zakładu i sam zakład ${ }^{5}$.

„Nawiązanie stosunku zakładowego może następować z mocy praw, na skutek indywidualnego aktu administracyjnego (decyzja o przyjęciu do zakładu) albo na skutek innego aktu lub czynności, jeżeli powstanie stosunku przewidują przepisy ustawy (skierowanie do zakładu). [...] Równie sformalizowany charakter musi mieć ustanie stosunku zakładowego"6.

${ }^{4}$ Uchwała składu siedmiu sędziów Naczelnego Sądu Administracyjnego z dnia 13 października 2003 r., sygn. OPS 5/03.

5 M. Elżanowski, Zakład Państwowy w polskim prawie administracyjnym, Warszawa 1970; E. Ochendowski, Zakład administracyjny jako portret administracji Państwowej, Poznań 1969; i inne pozycje tych autorów.

6 Z. Czarnik, J. Posłuszny, Zakład publiczny, [w:] System Prawa Administracyjnego, t. 6. Podmioty administrujące, red. R. Hauser, Z. Niewiadomski, A. Wróbel, Warszawa 2011, s. 469-470. 
W doktrynie podkreśla się także, że przy nawiązywaniu tak rozumianego stosunku zakładowego, z którego wynikać będzie władztwo zakładowe, musimy mieć zawsze wyraźną podstawę prawną rangi ustawowej ${ }^{7}$, co powiązane jest oczywiście $\mathrm{z}$ realizacją zasady legalizmu w funkcjonowaniu podmiotów wykonujących zadania z zakresu administracji publicznej.

Wszystkie wymienione założenia teoretyczne dotyczące funkcjonowania uczelni jako zakładów administracyjnych są w pełni realizowane w prowadzonych przez uczelnie studiach wyższych ${ }^{8}$ oraz studiach trzeciego stopnia (studia doktoranckie) $)^{9}$. Jesteśmy też $\mathrm{w}$ stanie wskazać $\mathrm{w}$ tych obszarach podstawy prawne indywidualnych aktów administracyjnych, będących fundamentem nawiązania stosunku zakładowego ${ }^{10}$, do których zgodnie z postanowieniami art. 207 PSW stosujemy przepisy kodeksu postępowania administracyjnego oraz ogólny katalog praw i obowiązków studenta albo doktoranta lub podstawy prawne do określenia ich w wewnętrznych regulaminach zakładowych.

Dokładna analiza Prawa o szkolnictwie wyższym w zakresie szczegółowej regulacji studiów podyplomowych, kursów dokształcających i szkoleń, a właściwie braków w tej regulacji, prowadzić może do krystalizowania się odmiennych wniosków co do charakteru więzi łączącej osoby korzystające ze wskazanych wyżej form dokształcania z uczelnią. Nie wpływa to oczywiście w sposób znaczący na dotychczasowe ustalenia doktryny w zakresie klasyfikowania szkół wyższych jako zakładów administracyjnych, jednakże może mieć doniosłe skutki dla obywateli. Odmienności te zdaje się już dostrzegać sądownictwo administracyjne, o czym dalej.

\section{STATUS SŁUCHACZA STUDIÓW PODYPLOMOWYCH ORAZ UCZESTNIKA KURSÓW DOSZKALAJĄCYCH I SZKOLEŃ}

Analizując Prawo o szkolnictwie wyższym, w łatwy sposób odnajdziemy przekazane uczelniom przez ustawodawcę w art. 13 ust. 1 pkt 6 zadanie publiczne dotyczące studiów podyplomowych, kursów i szkoleń. Zgodnie z tą regulacją do podstawowych zadań uczelni należy między innymi „prowadzenie studiów podyplomowych, kursów i szkoleń w celu kształcenia nowych umiejętności nie-

7 Ibidem, s. 469.

${ }^{8}$ Zgodnie z art. 2 ust. 1 pkt 5 PSW studia wyższe to studia pierwszego stopnia, studia drugiego stopnia lub jednolite studia magisterskie, prowadzone przez uczelnię uprawnioną do ich prowadzenia.

9 Zgodnie z art. 2 ust. 1 pkt 10 PSW studia trzeciego stopnia to studia doktoranckie prowadzone przez uprawnioną jednostkę organizacyjną uczelni, instytut naukowy Polskiej Akademii Nauk, instytut badawczy lub międzynarodowy instytut naukowy działający na terytorium Rzeczypospolitej Polskiej, utworzony na podstawie odrębnych przepisów, na które przyjmowani są kandydaci posiadający kwalifikacje drugiego stopnia, kończące się uzyskaniem kwalifikacji trzeciego stopnia.

10 Zob. art. 169 ust. 10 i 11 oraz art. 196 ust. 3 PSW. 
zbędnych na rynku pracy w systemie uczenia się przez całe życie”. Samo jednak ogólnie sformułowane zadanie nie wystarczy do stworzenia więzi administracyjnoprawnej, o której mowa przy studiach wyższych lub studiach trzeciego stopnia. Ustawodawca postanowił w Prawie o szkolnictwie wyższym wyraźnie zróżnicować status prawny studenta — osoba kształcąca się na studiach wyższych, doktoranta - uczestnik studiów doktoranckich i słuchacza - uczestnik studiów podyplomowych (pomijając przy okazji zupełnie status osób uczestniczących w kursach i szkoleniach ${ }^{11}$ ), przez co wykluczył możliwość odpowiedniego stosowania przepisów dotyczących studentów i doktorantów do osób uczestniczących w studiach podyplomowych, kursach i doszkoleniach prowadzonych przez uczelnie. W rezultacie tego zabiegu regulacje prawne dotyczące wymienionych trzech form edukacyjnych (form doszkolenia) są lakoniczne i ograniczają się właściwie wyłącznie do jednego przepisu merytorycznego ${ }^{12}$ oraz podstawowych definicji legalnych już przez nas przytoczonych. Studia podyplomowe, kursy i szkolenia nie są też objęte zakresem regulacji znajdującej się we wspominanym już art. 207 Prawa o szkolnictwie wyższym. W artykule tym wskazano między innymi, do których decyzji i aktów wydawanych przez uczelnie mają odpowiednie zastosowanie przepisy kodeksu postępowania administracyjnego oraz przepisy dotyczące możliwości zaskarżenia rozstrzygnięć do sądów administracyjnych. Reszta, a więc też kwestie dotyczące ustalenia kryteriów kwalifikacji na studia podyplomowe, kursy i szkolenia prowadzone przez uczelnię, zakres praw i obowiązków słuchacza oraz sytuacje powodujące skreślenie danej osoby z listy słuchacza lub uczestnika formy edukacyjnej (formy doszkolenia), nie została w ustawie nawet wspomniana. Można więc przyjmować, że ustawodawca pozostawił te kwestie do rozstrzygnięcia w ramach autonomii uczelni, o której mowa w art. 70 ust. 5 Konstytucji Rzeczypospolitej Polskiej ${ }^{13}$ oraz w art. 4 Prawa o szkolnictwie wyższym. Ze względu na niemożliwość nawiązywania stosunku zakładowego pod postacią indywidualnego aktu administracyjnego, z powodu braku wyraźnej podstawy prawnej, te aspekty ujęte powinny być w umowie o świadczenie usług edukacyjnych, podpisywanej między słuchaczem studiów podyplomowych albo uczestnikiem szkolenia lub kursu a szkołą wyższą prowadzącą określoną formę kształcenia.

11 Ustawodawca pominął w PSW kwestię określenia statusu uczestnika kursu dokształcającego lub szkolenia, o których mowa w art. 6 ust. 1 pkt 5 ustawy. Mając na względzie rosnącą popularność tych form doszkolenia, należy stwierdzić, że powinien to być status zbliżony do słuchacza studiów podyplomowych, a więc status odrębny od studenta czy doktoranta z wszystkimi konsekwencjami określonymi w niniejszym opracowaniu.

12 Zgodnie z art. 8a PSW studia podyplomowe trwają nie krócej niż dwa semestry. Program kształcenia powinien umożliwiać uzyskanie przez słuchacza co najmniej 30 punktów ECTS. Uczelnia jest obowiązana do określenia efektów kształcenia, uwzględniając ogólne charakterystyki efektów uczenia się dla kwalifikacji na poziomach 6 i 7 Polskiej Ramy Kwalifikacji, oraz do określenia sposobu ich weryfikowania i dokumentowania.

13 Konstytucja Rzeczypospolitej Polskiej z dnia 2 kwietnia 1997 r. (Dz.U z 1997 r. Nr 78, poz. 483 ze zm.). 
Alternatywnie mogą one być zebrane w ramach wewnętrznych regulaminów, do których przestrzegania zobowiązuje się konkretna osoba, podpisując wspomnianą umowę (a więc de facto będących częścią zawieranej umowy). „Stosunek prawny nawiązywany pomiędzy uczelnią a słuchaczem [czy uczestnikiem — M.W. i M.G.] ma charakter odmienny od stosunku łączącego studenta lub doktoranta z uczelnią, gdyż ma charakter cywilnoprawny"14. Dotychczasowa praktyka polskich uczelni wiązała się lub nadal wiąże z wydawaniem aktów na wzór decyzji administracyjnej o przyjęciu lub nieprzyjęciu na studia wyższe lub studia doktoranckie. Wiele wzorów tych aktów (można je znaleźć na stronach internetowych poszczególnych uczelni) jako główną podstawę prawną rozstrzygnięcia wskazuje (zapewne $\mathrm{z}$ braku podstawy prawnej w przepisach prawa materialnego) przepisy kodeksu postępowania administracyjnego oraz postanowienia wewnętrznych regulaminów dotyczących studiów podyplomowych. Praktyka taka może wprowadzać w błąd słuchaczy studiów podyplomowych bądź uczestników kursów i szkoleń co do więzi łączącej ich z uczelnią prowadzącą daną formę doszkolenia.

Jedna $\mathrm{z}$ takich spraw, co prawda dotycząca skreślenia $\mathrm{z}$ listy słuchaczy studiów podyplomowych, dała początek właściwej linii orzeczniczej kształtującej się obecnie w sądach administracyjnych. Naczelny Sąd Administracyjny w swoim postanowieniu ${ }^{15}$ oddalającym skargę kasacyjną na postanowienie Wojewódzkiego Sądu Administracyjnego w Warszawie ${ }^{16}$ słusznie stwierdził, że rozstrzygnięcie o skreśleniu z listy słuchaczy studiów podyplomowych nie podlega kontroli sądów administracyjnych, ponieważ Prawo o szkolnictwie wyższym, w myśl art. $3 \S 3$ ustawy Prawo o postępowaniu przed sądami administracyjnymi ${ }^{17}$, ,nie stanowi o właściwości sądów administracyjnych do kontroli i stosowania środków wobec rozstrzygnięć organów uczelni skierowanych do słuchaczy studiów podyplomowych, w tym rozstrzygnięć o skreśleniu z listy słuchaczy". Ingerowanie w obszary działania organów uczelni, niewskazane przez ustawodawcę wyraźnie w przepisach prawa, stanowiłoby naruszenie określonej w przepisach prawa zasady autonomiczności i niezależności szkół wyższych funkcjonujących w Rzeczypospolitej Polskiej. Już na etapie pierwszej instancji sądowoadministracyjnej słusznie podkreślono, że „racjonalny ustawodawca celowo różnicuje status studenta i doktoranta, jako podmiotów, których celem [w ramach - M.W. i M.G.] studiów I, II i III stopnia jest zdobycie ty tułu zawodowego lub [stopnia - M.W. i M.G.] naukowego oraz słuchacza studiów podyplomowych, które z kolei ukierunkowane są na pod-

14 T. Scheffler, Komentarz do art. 2 Prawa o szkolnictwie wyższym, [w:] Prawo o szkolnictwie wyższym. Komentarz, red. P. Chmielnicki, P. Stec, LEX 2017.

15 Postanowienie Naczelnego Sądu Administracyjnego z dnia 19 lutego 2016 r., sygn. I OSK 315/16.

16 Postanowienie Wojewódzkiego Sądu Administracyjnego w Warszawie z dnia 13 listopada 2015 r., sygn. II SA/WA 498/15.

17 Ustawa z dnia 30 sierpnia 2002 r. Prawo o postępowaniu przed sądami administracyjnymi (tekst jedn. Dz.U. z 2017 r. poz. 1369 ze zm.). 
wyższanie kwalifikacji, dokształcanie. W pierwszym przypadku przebieg studiów, warunki ich ukończenia i uzyskania stopnia zawodowego, naukowego podlega konkretnemu reżimowi prawnemu i kontroli państwa, w drugim zaś kwestie te zostały pozostawione w gestii szkoły wyższej w ramach przyznanej jej autonomii”.

Sąd pierwszej instancji podkreślił też, że z analizy przepisów ustawy Prawo o szkolnictwie wyższym jasno wynika, że ,nie w każdym przypadku kształtowanie stosunku prawnego szkoły wyższej z podmiotem poddającym się władztwu zakładowemu jest dokonywane w formie decyzji administracyjnej podlegającej kontroli sądowej”. Podstawowy w tych rozstrzygnięciach był również fakt zawarcia umowy, która ukształtowała stosunek cywilnoprawny. Postanowienia WSA i NSA nie zamykają więc możliwości swobodnego dostępu i dochodzenia swoich roszczeń przed niezawisłym i bezstronnym sądem, a jedynie wskazują na niewłaściwość ścieżki administracyjnoprawnej i konieczność wyboru sądu powszechnego ${ }^{18}$.

\section{PODSUMOWANIE I WNIOSKI}

Studia podyplomowe oraz krótsze formy dopuszczone przez ustawę Prawo o szkolnictwie wyższym - kursy dokształcające oraz szkolenia mogą być odpowiedzią uczelni wyższych na dynamicznie zmieniające się realia społeczno-gospodarcze oraz potrzebę szybkiej i wąskiej specjalizacji uczestników obrotu gospodarczego. Obecne regulacje w tym zakresie, a w szczególności zróżnicowanie pozycji prawnej słuchaczy studiów podyplomowych (i uczestników kursów dokształcających oraz szkoleń) w stosunku do studentów i doktorantów oraz wyłączenie w tym pierwszym przypadku możliwości stosowania przepisów kodeksu postępowania administracyjnego i kontroli sądowoadministracyjnej nad aktami do nich kierowanymi doprowadziły do zmiany pierwotnego administracyjnoprawnego charakteru relacji łączącej słuchacza studiów podyplomowych (użytkownika zakładu administracyjnego) i uczelnię (zakład administracyjny). Przejście do więzi wynikającej ze stosunku cywilnoprawnego, opartego na umowie o świadczenie usług edukacyjnych, zbliżyło uczelnie (w wypadku prowadzenia studiów podyplomowych, kursów dokształcających i szkoleń) do pozycji przedsiębiorcy funkcjonującego w obszarze kształcenia i dostarczającego odpłatne produkty, a nie zakładu administracyjnego realizującego zadania publiczne z dziedziny świadczeń o szczególnym znaczeniu społecznym. Niezależnie od potencjalnych rozważań

18 Od momentu wydania postanowienia przez NSA wojewódzkie sądy administracyjne podjęły już kilka podobnych rozstrzygnięć co do więzi prawnej łączącej słuchacza studiów podyplomowych i uczelnię prowadzącą tę formę dokształcania. Zob. postanowienia: WSA w Poznaniu z dnia 22 lutego 2017 r., sygn. II SA/Po 642/16; WSA w Warszawie z dnia 3 lutego 2017 r., sygn. II SA/Wa 52/17; WSA w Warszawie z dnia 16 stycznia 2017 r., sygn. II SA/Wa 2213/16; WSA w Warszawie z dnia 9 stycznia 2017 r., sygn. II Sa/Wa 2212/16; WSA w Warszawie z dnia 1 sierpnia 2016 r., sygn. II SAB/Wa 409/16. 
o wadach i zaletach takiego ukształtowania stosunku prawnego między słuchaczami (uczestnikami kursów i szkoleń) a uczelnią podkreślić należy, że prawo o szkolnictwie wyższym dopuszcza w art. 7 możliwość prowadzenia przez uczelnie wyodrębnionej organizacyjnie i finansowo działalności gospodarczej, w szczególności w formie spółek kapitałowych, jednakże działalność ta ma być inna niż realizacja podstawowych zadań, do których zaliczamy obecnie prowadzenie studiów podyplomowych, kursów dokształcających i szkoleń. Być może zmiana ustawowa w tym zakresie i dopuszczenie przesunięcia coraz bardziej specjalistycznych usług edukacyjnych do wyodrębnionych centrów szkoleniowych, korzystających z doświadczenia, infrastruktury i wykwalifikowanej kadry uczelni, pozwoliłoby na jeszcze lepsze reagowanie na potrzeby społeczne i rynkowe. W niniejszym opracowaniu celowo pominięto projektowane regulacje tak zwanej ustawy 2.0, ze względu na trwające cały czas uzgodnienia i konsultacje, które w sposób znaczący mogą wpłynąć na treść projektu skierowanego do prac parlamentarnych.

\section{THE CHANGING ROLE OF ACTIVITY OF POLISH UNIVERSITIES CONCERNING POSTGRADUATE COURSES, SUPPLEMENTARY COURSES AND TRAININGS}

Summary

Legal diversification of the status of a student of postgraduate courses (as well as supplementary courses and trainings) in relation to the status of student and doctoral student, resulting from the Higher Education Law, caused a transformation of the primary administrative-law relationship into a civil law relationship, based on a contract, not an administrative act. As a result, the possibility of applying to students of postgraduate courses the provisions of the Code of Administrative Procedure was excluded and it became impossible to obtain control exercised by administrative courts due to a purely contractual bond covered by the jurisdiction of common courts.

Keywords: postgraduate courses, supplementary courses, trainings, administrative establishment, university, autonomy

\section{BIBLIOGRAFIA}

Czarnik Z., Posłuszny J., Zakład publiczny, [w:] System Prawa Administracyjnego, t. 6. Podmioty administrujace, red. R. Hauser, Z. Niewiadomski, A. Wróbel, Warszawa 2011.

Elżanowski M., Zakład Państwowy w polskim prawie administracyjnym, Warszawa 1970.

Ochendowski E., Zakład administracyjny jako podmiot administracji państwowej, Poznań 1969.

Scheffler T., Komentarz do art. 2 Prawa o szkolnictwie wyższym, [w:] Prawo o szkolnictwie wyższym. Komentarz, red. P. Chmielnicki, P. Stec, LEX 2017. 